\title{
PEMIKIRAN TEOLOGI TEOSENTRIS MENUJU ANTROPOSENTRIS HASAN HANAFI
}

\author{
Achmad Faisol Haq \\ Institut Agama Islam Uluwiyah Mojosari Mojokerto \\ faisolhaq01@gmail.com
}

\begin{abstract}
Theology is the foundation for a religion, whereas the thought of the theology of a thinker, will have a very significant impact in the reality of life, because being a religious foundation, the theology is a foothold in the behavior of a person, therefore in today's contemporary period there needs to be a theology that can be applied in daily life, the discussion of a theology is not only theological, but also needs a theology that anthropocentric, this anthropocentric theology, carried out by Hasan Hanafi, is based on a theoccentric theology whose nature is digitized in the dilectic of the discussion, then under the anthropocene so that it can be directly implemented in the daily life of society. In this study tried to examine the theological thinking towards the anthropocentric Hasan Hanafi. This research is a library study, looking for sources of references related to the theme of research, as well as taking from the opinions of various figures, then elaborated and observed until it becomes a research paper.
\end{abstract}

Keywords: Hasan Hanafi, Theoccentric, Anthropocene.

\section{A. Pendahuluan}

Teologi sangat berhubungan erat dengan sikap dan perilaku orang-orang yang meyakininya. Karena konsep teologi yang diyakini oleh seseorang akan menjadi dasar dalam menjalani kehidupannya. Seperti halnya kaum Jabariyyah (fatalism) meyakini bahwa manusia tidak mempunyai kewenangan untuk menentukan takdirnya, membuat tingkah laku yang berfaham seperti ini dalam keseharian lebih banyak mengandalkan tawakkal dan kurang berikhtiyar. Menurut

Spiritualis, vol. 6, no. 2, September 2020

ISSN: 2442-5907|159 
Hasan Hanafi, teologi Islam yang dianut oleh mayoritas umat Islam saat ini belum bisa mengantarkan kepada keyakinan atau pengetahuan yang meyakinkan tentang Tuhan dan wujudwujud spiritual lainnya, akan tetapi baru pada tahap mendekati keyakinan. ${ }^{1}$

Menurut Hasan Hanafi konsep teologi yang dianut umat Islam saat ini lebih berisi konsep-konsep yang melangit dan ide-ide kosong, bukan ide-ide real yang bisa menuntun umat untuk menjalani kehidupan nyata dan seakan-akan konsep tersebut seperti asing bagi dirinya sendiri dan orang banyak. ${ }^{2}$ Dalam kenyataannya, konsep teologi yang berkembang saat ini hanya digunakan untuk mempertahankan dogma yang bersifat teosentris saja dari pada mendiskusikan permasalahan-permasalahan yang berkaitan dengan kehidupan individu dan sosial manusia yang bersifat antroposentris. Jika melihat kembali kepada sejarah masa lalu, yang sangat mungkin juga terjadi pada saat ini, pemikiran teologi kerap dijadikan persembahan kepada penguasa saat itu untuk melanggengkan kekuasaannya sehingga tidak jarang terjadi pemaksaan dan pertumpahan darah dalam perjalanannya. Padahal seharusnya pemikiran teologi bisa menjadi konsep yang membebaskan manusia dan bisa menjadi dasar utama motivasi manusia kearah kemandirian, kesadaran dan kemajuan.

Jika melihat pada sejarah, fase-fase terakhir pemerintahan al-Khulafā al-Rāshidūn, usaha dan semangat pembebasan masyarakat dari ketertindasan, diskriminasi dan ketidak-adilan sosial, sudah mulai tampak memudar dari ritme

1 A. Khudori Sholeh, Filsafat Islam (Sleman: Ar-Ruzz Media, 20014), 63.

2 Hasan Hanafi, Agama, Ideologi, dan Pembangunan (Jakarta: P3M, 1991), 408-409. 
Spiritualis: vol. 6, no. 2, September, 2020 |161

kehidupan umat Islam pada saat itu. Hal ini bisa terjadi karena selama pemerintahan empat khalifah tersebut, umat Islam disibukkan menyebar-luaskan agama Islam. ${ }^{3}$ Ekspansi secara besar-besaran yang mengakibatkan terjadinya persentuhan agama Islam dengan budaya asing, khususnya dengan pemikiran-pemikiran Yunani, telah mengakibatkan munculnya suatu aliran-aliran teologi baru yang lebih mengedepankan term-term filosofis. Di samping itu, juga terjadi atas dorongan faktor-faktor politis. ${ }^{4}$

Oleh karena itu, suatu pemikiran dan perdebatanperdebatan teologi yang muncul dan berkembang waktu itu, bersifat defensif apologetik ${ }^{5}$. Suatu struktur logika teologi lebih berbentuk dialektika Hegelian, bukan dialektika Marxian ${ }^{6}$, yang mempunyai orientasi pembahasan menentang ketidak-adilan dan penindasan serta pemihakan kepada rakyat miskin. Teologi yang bersifat dialektik ini, lebih diarahkan untuk mempertahankan doktrin dan memelihara kemurnianya, bukan dialektika konsep tetang corak sosial dan sejarah, disamping juga bahwa ilmu kalam sering disusun sebagai wujud persembahan kepada para penguasa yang dianggap sebagai wakil Tuhan di bumi. Sehingga pemikiran teologi pada saat itu - terlepas dari sejarah dan pembicaraan tentang manusia cenderung hanya menjadi alat legitimasi bagi status quo dari

3 Asghar Ali Enginer, Islam dan Teologi Pembangunan, terj. Agung Prihantoro (Yogyakarta: Pustaka Pelajar,1999), 15.

${ }^{4}$ Ishlah Gusmian, Teologi Pembebasan dari Membela Manusia: Sekilas Gagasan Ashgar Ali Enginer, dalam Muhiddin M. Dahlan (ed), Sosialisme Religius (Yogyakarta:Kreasi Wacana, 2010), 221.

5 Abdul Hadi Abu Riddah, Ummahāt al-Masāil Fi Fikri al-Islämi, dalam Al-Qabas nomor 6343, 05 Januari 1990.

${ }^{6}$ Islah Gusmian, Teologi, 193. 
Spiritualis: vol. 6, no. 2, September, 2020 |162

pada sebagai pembebas dan penggerak manusia ke arah kemandirian dan kesadaran. ${ }^{7}$ Berkenaan dengan hal itu, Hasan Hanafi berpendapat bahwa teologi yang notabene sebagai konsepsi inti dalam diri dan pandangan Islam, mutlak harus dibenahi.

Sesuai dengan perkembangan zaman, dunia Islam membutuhkan suatu dimensi teologi Islam yang bersifat tajriby (empirik), sebagai teologi yang lebih bersifat "membumi" daripada konsepsi yang bersifat "melangit" seperti yang terjadi selama ini. Dialektika-teologis terus berkelanjutan sepanjang sejarah peradaban manusia, sesuai dengan konteks zaman yang melingkupinya. Bagaimana pun, teologi tidak berarti hanya membahas mengenai iman an-sich saja. Jika iman masih bersifat "pure matter" atau substantif, maka teologi hanya bersifat metodologik. ${ }^{8}$ Oleh karena itu Hasan Hanafi mempunyai gagasan tersendiri mengenai sebuah teologi. Awalnya sebuah teologi hanya memuat teori-teori "melangit" (teosentris) kemudian dibawa dalam sendi kehidupan masyarakat yang lebih bersifat "membumi" (antroposentris). Dalam tuliasn ini akan membahas tentang pemikiran teologi Hasan Hanafi dari teosentris menuju antroposentris.

\section{B. Biografi Hasan Hanafi}

Hasan Hanafi merupakan salah satu tokoh kontemporer intelektual Islam pada saat ini, ia lahir pada tanggal 13 Februari tahun 1935 di Kairo, Mesir tepatnya di

7 AH. Ridwan, Reformasi Intelektual Islam, Pemikiran Hasan Hanafi tentang Reaktualisasi Tradisi keilmuan Islam (Yogyakarta: Ittaqa Press, 1998), 44-45.

${ }^{8}$ Muhammad Azhar, dkk, Studi Islam dalam Percakapan Epistemologis (Yogyakarta: Sipres, 1998), 166. 
Spiritualis: vol. 6, no. 2, September, 2020 |163

dekat Benteng Salahuddin, daerah perkampungan Universitas Al-Azhar, Kairo. Kota ini merupakan tempat bertemunya para mahasiswa muslim dari berbagai belahan dunia yang ingin belajar, terutama di Universitas Al-Azhar. Hasan Hanafi tumbuh menjadi seorang filosof dan teolog di Mesir yang meraih gelar sarjana muda dalam bidang ilmu filsafat di Universitas Kairo pada tahun 1956. ' Dilihat secara kultural, Mesir merupakan sebuah tempat bertemunya peradaban besar di dunia. Mulai masa yang paling awal, seperti masa Fir'aun, Bizantium, Romawi, Arab, dinasti Mamluk dan Turki sampai dengan Eropa Modern pada saat ini. Akan tetapi, kehidupan kecil Hasan Hanafi dihadapkan pada kenyataan kehidupan yang pahit di bawah naungan kekuasaan penjajahan dari pengaruh-pengaruh politik asing yang lain. ${ }^{10}$

Hasan Hanafi mengenyam pendidikan sekolah dasar di Madrasah Sulayman Ghawish, lulus tahun 1948. Kemudian melanjutkan studinya pada tingkat pertama di Madrasah Sanawiyah "Khalil Alga", Kairo yang diselesaikannya selama empat tahun, lulus pada tahun 1952. Semenjak masih remaja kesadaran pertama yang tumbuh dalam diri Hasan Hanafi adalah "kesadaran nasional" (national consciousness), pertumbuhan kesadaran ini terkait dengan realita situasi Mesir pada saat itu yang mana dalam Perang Dunia ke-II menjadi sasaran serangan Jerman. Semangat nasionalisme mendorong Hanafi untuk terjun sukarela membantu pejuang-perjuang Mesir dalam perang melawan Zionis Israel. Akan tetapi dengan segera ia menyadari adanya perpecahan yang tidak bisa

\footnotetext{
${ }^{9}$ Hamzah, Teologi Sosial: Telaab Pemikiran Hasan Hanafi (Yogyakarta: Graha Ilmu, 2013), 11.

10 Moh Nurhakim, Neo Modernisme dalam Islam (Malang: UMM Press, 2001), 199.
} 
Spiritualis: vol. 6, no. 2, September, 2020 |164

diselesaikan di antara bangsa-bangsa Arab sendiri dalam menghadapi Israel dan sangat merugikan Mesir khususnya. ${ }^{11}$

Menyimpan rasa frustasi yang sangat pahit terhadap realitas nasionalisme Arab sekuler yang gagal menyatukan bangsa-bangsa Arab, Hasan Hanafi secara alamiah bergeser kepada ajaran Islam. Ia kemudian melanjutkan studinya ke Universitas Kairo, dan aktif mengikuti diskusi-diskusi kecil kelompok Ikhwanul Muslimin (IM) yang pada saat itu sedang menemukan momentumnya, bukan karena IM berdiri paling depan melawan Israel, tetapi juga karena ia percaya bahwa organisasi ini mampu mengcouter sosialisme-komunisme yang semakin kuat dalam lingkaran para penguasa Mesir. Hasan Hanafi juga mulai aktif mengikuti demonstrasi-demonstrasi IM dan politik mahasiswa di Universitas Kairo. ${ }^{12}$

Pada akhir tahun 1950an "kesadaraan keagamaan (religious consciousness) dalam diri Hasan Hanafi mulai bangkit. Pemikirannya bertolak dari motif-motif Islam. Pada masa inilah ia mengenal secara lebih mendalam pemikiran dan wacana Islam yang berkembang di lingkungan gerakan-gerakan Islam (harakah). Sejak itu Hasan Hanafi berkonsentrasi untuk mendalami pemikiran agama, revolusi, dan permasalahan perubahan sosial. $^{13}$

Setelah lulus dari Universitas Kairo Mesir, ia melanjutkan studi pendidikannya di Universitas Sorbonne

11 Moh Hefni, "Rekonstruksi Maqashid al-Syariah (Sebuah Gagasan Hasan Hanafi tentang Revitalisasi Turats), Jurnal al-Hikam. Vol. 6 No. 2 Desember $2011,168$.

${ }^{12}$ Hasan Hanafi, Dari Akidah ke Revolusi: Sikap Kita Terhadap Tradisi Lama, Terj. Miftah Faqih (Jakarta: Paramadina, 2003), 13.

13 A H. Ridwan, Reformasi Intelektual Islam: Pemikiran Hasan Hanafi Tentang Reaktualisasi Tradisi Islam Keilmuan Islam (ITTAQA Press, 1998), 15. 
Spiritualis: vol. 6, no. 2, September, 2020 |165

Perancis. Ia mengambil bidang studi spesialisasi Filsafat Barat Modern dan Pra Modern. Pada saat di Perancis inilah Hanafi mematangkan keilmuan filsafatnya. Di sana, Hasan Hanafi merasakan sangat berarti bagi perkembangan pemikirannya, dan di Perancis inilah ia berlatih nalar berfikir secara metodologis, baik melalui kuliah-kuliah ataupun bacaan-bacaan karya orientalis. Disamping itu Hasan Hanafi juga tertarik untuk mendalami pemikiran-peikiran filsafat Idealisme Jerman, terutama filsafat dialektika yang lazim dalam pemikiran filusuf Hegel dan Marx. ${ }^{14}$

Pada masa inilah Hasan Hanafi mencoba mulai merumuskan kembali "proyek besar"-nya untuk menciptakan metodologis dan teologi baru dalam Islam, tentunya dengan sebuah pendekatan-pendekatan baru pula. Dalam kerangka itu Hasan Hanafi mengajukan rancangan disertasi di Universitas Sorbone dengan judul "The General Islamic Method". Judul ini mewakili keinginannya untuk merumuskan Islam sebagai jalan metodologis yang umum dan komprehensif dalam kehidupan secara personal dan sosial. ${ }^{15}$

Orang yang sangat berjasa dalam pemikiran filosofis Hasan Hanafi adalah Jean Guitton, seorang Guru Besar dalam bidang ilmu filsafat dan meupakan pentolan modernis Katolik Roma. Dialah yang memandu Hasan Hanafi dalam pembacaan tentang studi filsafat Barat. Jean Guitton juga yang memberikan panduan kepada Hanafi dalam hal-hal praktis, seperti bagaimana memberikan kuliah umum dan metodemetode penelitian. Metode dan perspektif umum Guitton

${ }_{14}$ Hasan Hanafi, Islamologi 3: Dari Teosentrisme ke Antroposentrisme, Terj. Miftah Faqih (Yogyakarta: LKis 2004), X.

15 A H. Ridwan, Reformasi Intelektual Islam...., 14. 
sangat dominan bagi pengembangan pemahaman Hanafi tentang pendekatan-pendekatan untuk rekonsiliasi posisi yang berbeda. Hasan Hanafi banyak belajar mengenai urgensiurgensi starting point dalam filsafat. Filsafat membutuhkan sebuah titik permulaan yang kemudian dikembangkan dan diperdalam oleh seorang filsuf, setelah itu digeneralisasikan sedemikian rupa hingga sampai pada sebuah gagasan metafisika murni. Jean Guitton adalah orang yang sangat berpengaruh bagi kesadaran Hasan Hanafi tentang kehidupan, transformasi dari sebuah idealisme ke realism, dan transformasi dari pikiran ke eksistensi. ${ }^{16}$

Karakteristik lain dari pemikiran Hasan Hanafi pada dasawarsa 1960-an banyak di pengaruhi oleh faham-faham yang dominan berkembang di Mesir, yaitu nasionalistiksosiolistik-populistik yang dirumuskan sebagai ideologi Pan Arabik. Baru pada akhir dasawarsa itu Hasan Hanafi mulai berbicara tentang keharusan Islam untuk mengembangkan wawasan kehidupan yang lebih progresif dan berdimensi pembebasan (al-taharrur, liberation). Ia mensyaratkan fungsi pembebasan jika diharapkan pada ajaran Islam dapat membawa masyarakat pada kebebasan dan keadilan, khususnya keadilan sosial sebagai ukuran utamanya. ${ }^{17}$

Pada tahun 1966, ia berhasil menyelesaikan program Doktornya di Universitas Sorbone, ia memperoleh gelar doctor dengan desertasinya yang berjudul Essai Sur La Methode d'Exegese (Essai tentang Metode Penafsiran). ${ }^{18}$ Karir Hasan Hanafi dimulai dengan diangkatnya menjadi Rektor (1980)

\footnotetext{
16 Hasan Hanafi, Islamologi..., xviii.

17 A.H Ridwan, Reformasi Intelektual Islam..., 15.

18 Hasan Hanafi, Islamologi..., xviii.
} 
pada jurusan ilmu filsafat di Universitas Kairo. Kemudian mulai tahun 1988, ia diserahi jabatan sebagai ketua jurusan filsafat di universitas yang sama. Suasana Mesir sendiri pada saat itu baik secara politik maupun secara intelektual kurang kondusif baginya. Sehingga Hanafi mengembara ke negara lain dan aktif memberi perkuliahan-perkuliahan seperti di Prancis (1969), Belgia (1970), Temple Universitas Philadelphia Amerika Serikat (1971-1975), Universitas Kuwait (1979), Universitas Fez Maroko (1982-1984) dan menjadi guru besar tamu di Universitas Tokyo (1984-1985), di Persatuan Emirat Arab (1985), kemudian diangkat menjadi seorang penasehat program pada Universitas PBB di Jepang (1985-1987) dan sekembalinya dari Jepang pada 1988 ia diserahi jabatan ketua jurusan filsafat di Universitas Kairo. ${ }^{19}$

Selain aktivitas dalam dunia akademik yang ditunjang dengan aktivitas di organisasi masyarakat, Hanafi aktif sebagai sekretaris umum Persatuan Masyarakat Filsafat Mesir. Ia juga menjadi anggota Ikatan Penulis Asia-Afrika, juga menjadi anggota gerakan Solidaritas Asia-Afrika serta menjabat Wakil Presiden Persatuan Masyarakat Filsafat Arab. ${ }^{20}$ Pemikiranpemikiran Hasan Hanafi tersebar mulai di dunia Arab hingga ke Eropa. Pada tahun 1981, ia memprakarsai dan sekaligus menjadi pimpinan redaksi jurnal ilmiah dengan Al-Yasar alIslami. Pemikirannya yang terkenal dengan Al-Yasar al-Islami

19 Suharti, "Gagasan Kiri Islam Hasan Hanafi", Ulumuna, Vol. IX Edisi 16 Nomor 2 Juli-Desember 2005. 357.

${ }^{20}$ Ibid., 358. 
Spiritualis: vol. 6, no. 2, September, 2020 |168

sempat mendapat reaksi dari penguasa Mesir pada saat itu Anwar Sadat yang memasukannya ke dalam penjara. ${ }^{21}$

Hasan Hanafi sangat banyak menyerap pengetahuan Barat dan mengkonsentrasikan diri pada kajian-kajian pemikiran Barat modern dan pra modern. Karena itu meskipun ia menolak dan mengkritik Barat, seperti halnya disebutkan Kazuo Shimogaki, ide-ide liberalisme Barat, demokrasi, rasionalisme dan pencerahan telah mempengaruhinya, sehingga Shimogaki juga mengkategorikannya sebagai seorang modernis liberal. ${ }^{22}$

\section{Teologi Teosentris Menuju Antroposentris}

Dalam tradisi keagamaan Islam, teologi ('aqīdah) dipandang sebagai sebuah unsur penting yang mendasari adanya sebuah agama, tanpa teologi yang menjadi dasar keimanan seseorang, maka tidak ada agama. Oleh karena itu teologi menjadi sebuah bidang kajian yang telah mentradisi dalam semua agama. Bahkan sejarah-sejarah agama itu sendiri pada dasarnya adalah sejarah teologi. Ratusan hingga ribuan buku telah ditulis orang untuk memperbincangkan masalah teologi, yang mana semuanya bertujuan untuk mensucikan (tan $2 \bar{i} \bar{b})$ Tuhan. $^{23}$

Teologi (ilmu kalam) sebagaimana yang dijelaskan oleh Nurcholis Madjid, merupakan sebuah bidang strategis sebagai

21 Yusdani, "Gerakan Pemikiran Kiri Islam: Studi Atas Pemikiran Hasan Hanafi”, Jurnal Al-Mawarid Edisi VII 2002. 81.

${ }^{22}$ Kazuo Shimogaki, Kiri Islam: Antara Modernisme dan Posmodernisme, terj. M. Imam Aziz dan M. Jadul Maulana (Yogyakarta: LKis, 2007), 3.

${ }_{23}$ Rumadi, Masyarakat Post-teologi, Wajah Baru Agama dan Demokratisasi Indonesia (Jakarta: CV Mustika Bahmid, 2002), 23. 
landasan upaya pembaharuan pemahaman dan pembinaan umat Islam, karena sifatnya yang sangat metodologis. ${ }^{24}$ Senada dengan penjelasan di atas Gustavo Gutterez menjelaskan bahwa teologi merupakan aspek yang sangat penting karena dapat berfungsi sebagai sebuah refleksi kritis dalam tindakan manusia untuk melihat suatu realitas sosial yang dihadapinya. ${ }^{25}$

Ilmu tentang Tuhan (teologi/kalam), dalam diskursus keislaman sesungguhnya mengalami pembakuan-pembakuan akan tetapi bersifat "demanding" (banyak permintaan). Sayangnya ketika permintaan itu dicari jawabannya, maka kita menemukannya dalam sebuah dogma: janganlah engkau berpikir tentang Tuhan, tetapi pikirkanlah tentang ciptaan Tuhan. Sebab, siapa mengetahui Tuhan, dia mengetahui dirinya. Barang siapa yang mengenal dirinya, maka mengenal Tuhan. Memperbincangkan mengenai Tuhan dalam ajaran Islam menjadi imposible area (daerah ketidak mungkinan untuk dicari jawaban-jawaban tegasnya). Nabi Muhammad SAW, menyebutnya dengan, Qul al-rü̧u min amri rabbi (Katakanlah, sesungguhnya ruh adalah urusan Tuhan). Sedangkan Karens Amstrong menyebutnya, Tuhan menjadi transenden personalistik (jauh dan milik prifat) dan gagasan ini, seringkali dituduh sebagai sebuah gagasan pembeda (furqān) dari teologi dalam Kristiani yang telah imanen (kehadiran Tuhan dalam setiap aktivitas manusia). ${ }^{26}$

\footnotetext{
${ }^{24}$ Nurcholis Madjid, Aktualisasi Ajaran Aswaja, dalam Islam Menatap Masa Depan (Jakarta; P3M, 1989), 61.

${ }^{25}$ Gustavio Gutterez, A Teology of Liberation (New York: Maryknell, 1973), 5.

${ }^{26}$ Airlangga Pribadi \& M. Yudhie R. Haryono, Post Islam Liberal Membangun Dentuman Mentradisikan Eksperimentasi (Jakarta PT. Pasarindo Bunga Mas Nagari, 2002), 89-90
} 
Spiritualis: vol. 6, no. 2, September, 2020 |170

Berbicara mengenai relasi Tuhan dengan manusia, secara mainstream dalam kajian teologi selalu bersifat teosentris, di mana Tuhan menjadi pusat segala dari kekuatan dan kekuasaan, sedangkan manusia diharuskan tunduk dan ditundukkan di hadapan Tuhan. Di tengah-tengah keruwetan pembahasan mengenai teologi, banyak orang mulai mempertanyakan apa kaitanya teologi untuk menyelesaikan masalah-masalah sosial yang tumbuh dalam kehidupan manusia. Pertanyaan ini sering muncul karena teologi, alih-alih menjawab sebuah problem kemanusiaan, dalam banyak hal justru teologi digunakan sebagai alat untuk melakukan penindasan terhadap manusia. Oleh karena itu, teologi bukan sarana untuk melakukan transformasi masyarakat. Tapi lebih sebagai suatu bidang kajian untuk "mentransformasikan Tuhan."27

Cara berfikir dikotomis ini, menganggap agama adalah cara orang untuk bertuhan (teologi teosentris), suatu teologi yang mengajak kepada manusia untuk "meninggalkan segalagalanya" demi Tuhan. Logika berfikirnyanya, karena kita semua berasal dari Tuhan maka kepada Tuhanlah kita serahkan segalanya (Innā lillăbi wa innā ilaybi räjisuñ). Sebab segalanya (dunia dan nasib manusia) tidak begitu penting kecuali Tuhan sendiri. ${ }^{28}$

Masih berhenti pada kepercayaan kepada "Tuhan" meskipun sebenarnya pengertian teologi teosentris tersebut menghasilkan dampak-dampak yang baik, berupa adanya pegangan hidup bagi manusia, meski juga dampak itu sendiri

27 Rumadi, Masyarakat Post Teologi..., 23.

28 Airlangga Pribadi, Post Islam Liberal, 94-95. 
bisa saja palsu. Akan tetapi dalam prespektif Nurcholis Madjid, justru yang lebih jelas berbahaya dan nyata-nyata merugikan manusia adalah dampak kesampingnya, yaitu pembelengguan secara pribadi dan pemrosotan harkat dan kemanusiaan. ${ }^{29}$ Kepercayaan dalam sebuah pengertian ini belum pada kepercayaan kepada "Tuhan", maka sudah menjadi suatu kewajiban perlunya shifting paradigm (pergeseran paradigma) dalam bidang teologi (ilmu kalam). Karena kalau sebuah teologi hanya berbicara tentang Tuhan (teosentris) dan tidak mengkaitkan diskursus pembahasanya dengan persoalan kemanusiaan secara universal (antoposentris), maka rumusan teologinya lambat-laun akan terjadi out of date. ${ }^{30}$

Counter terhadap pemikiran yang menganggap agama sebagai cara orang untuk mempercayai Tuhan saja (teosentris), melahirkan sebuah tafsir dan cara pandang yang sebaliknya, yaitu agama adalah cara orang untuk memanusiakan-manusia. Dalam cara pemahaman agama yang seperti ini, melahirkan sebuah teologi antroposentris. Suatu teologi yang menempatkan manusia sebagai pusat dari segalanya. Tuhan telah menciptakan alam semesta. Oleh karena itu manusia bebas (free-sekuler) untuk menentukan dirinya sendiri sebagai pusat dari segalanya. Sebab inti agama adalah cara untuk bersifat humanis dan menyejahterakan manusia. Akibatnya adalah, diskursus mengenai ekoreligi sebagai contoh, didasarkan pada nilai-nilai kapitalis dan sekuler yang anti pelestarian lingkungan; sebuah fokus yang menempatkan manusia itu sendiri sebagai raja yang sah untuk mengeksploitasi

${ }^{29}$ Nurcholis Madjid, Iman dan Emansipasi, 99-100.

30 Amin Abdullah, Filsafat Kalam di Era Postmodernisme (Yogyakarta: Pustaka Pelajar, 1995), 42. 
seluruh kekayaan alam yang berdasarkan untung-rugi bagi kepentingannya. "Manusia tidak salah apalagi berbuat berdosa" atas perilaku tersebut. ${ }^{31}$ Ini adalah sebuah konsekuensi yang akan diterima, akan tetapi tidak semutlak itu. Bagi Hasan Hanafi teologi antroposentris harus tetap tidak lepas dari teologi teosentris itu sendiri.

Dalam bukunya Min al-Aqidah Ila al-Thawrab; Mubawalatun Li I'adàt Binà' $\operatorname{Im}$ Ușù al-Dīn (dari akidah ke revolusi; upaya untuk membangun kembali ilmu ushuluddin), Hasan Hanafi memberikan kritiknya terhadap karya pemikiranpemikiran ilmu kalam (teologi) terdahulu sebagai sesuatu hal yang sangat jauh dari etos progesivitas kemanusiaan, yang selalu mensubordinasikan manusia. Dalam referensi-refernsi teologi tersebut, pertama-pertama selalu diungkapakan pujipujian kepada Allah dan sebuah pernyataan kelemahan manusia di hadapan ke-Maha-Besaran-Nya yang mana telah memberikan pengaruh penanaman nilai pasivitas ke dalam diri manusia itu sendiri serta menciptakan suatu kondisi yang secara psikologis tidak mampu mengubah keadaan. Jiwa seorang diperkedil dan diperlemahkan dengan selalu menjejalkan pemikiran seperti itu dalam kesadaran manusia. Manusia selalu mengingat bahwa Dia yang Maha Besar, sementara diri sendiri serba lemah dan selalu membutuhkan pertolongan. Sikap yang seperti ini, sedemikian terpatri dalam jiwa manusia, dampaknya membuat orang tak percaya diri terhadap dirinya dan tidak berkuasa ketika berhadapan dengan penguasa-penguasa yang temporal, baik itu penguasa politik, penguasa budaya maupun penguasa keagamaan itu sendiri.

31 Airlangga Pribadi, Post Islam Liberal..., 95. 
Kehilangan era progesifitasnya dalam melakukan sebuah perubahan, ${ }^{32}$ inilah akar dari metodologis teologi (kalam) klasik yang harus dirombak secara menyeluruh, mestinya, menurut Hasan Hanafi, risalah dalam kajian ilmu kalam harus diawali dengan pernyataan-pernyataan "demi bumi kaum muslimin yang sedang terjajah, demi kebebasan kaum muslimin dalam menghadapi serangan musuh, demi keadilan sosial dan persamaan dan seterusnya." 33

Kritikan Hasan Hanafi atas tradisi pemikiran teologi (kalam) klasik tersebut di dasarkan pada sebuah realitas di mana dia memandang pentingnya sebuah upaya revitalisasi dan reaktualisasi keilmuan kalam dalam konteks kehidupan masa kini. Keilmuan teologi (kalam) yang selama ini diklaim mandul mestinya harus disegarkan kembali sehingga mampu berdialektika dengan sebuah realitas kekinian dan dapat melahirkan paradigma-paradigma baru sesuai dengan tuntutan zaman. Keilmuan teologi yang berkembang pada umat Islam selama ini hanya bersifat teosentris saja, teologi (ilmu Kalam) yang dalam pembahasannya senantiasa lekat dengan masalahmasalah al-iläbijyat, al-mantiquiyat dan al-täbi'iyat merupakan kajian teologi (ilmu kalam) dalam realitasnya old fashion. ${ }^{34}$

Harus diakui, tradisi teologi Sunni tidak mempunyai parangkat sosial yang bisa untuk menjawab berbagai problemproblem yang terjadi pada masyarakat, tidak mampu bergulat dalam "anarki pemaknaan" serta gagap dalam mengakomodir

${ }^{32}$ Hasan Hanafi, Min al-'Aqidah Ila al-Thawrah; Mụ̣awalatun Li I'ädat Bina' Usūl al-Din (Kairo: Maktabah Madbuli. t.th), 5.

33 Ibid., 31.

${ }^{34}$ Hasan Hanafi, Dirāsah Islämiyyah (Kairo: Maktabah al-Mishriyyah, t.th), 394415. 
Spiritualis: vol. 6, no. 2, September, $2020 \mid 174$

derasnya dinamika sosial yang terjadi, dan rapuh untuk menjadikan pijakan bagi pemberdayaan masyarakat yang lebih berorientasi kepada masalah-masalah sosial, kemanusiaan dan kerakyatan. Kritik yang semacam ini bukan sebuah hal yang mengada-ada, akan tetapi merupakan kegelisahan banyak orang yang menyadari pentingnya teologi dalam proses transformasi dan pemberdayaan manusia, sesuatu yang tidak ditemukan dalam kajian teologi konvensional yang sebagian besar berputar-putar pada "peradaban teori" yang bersifat melangit dan hampir-hampir tidak ada kaitannya dengan manusia itu sendiri. Tema-tema yang diangkat dalam teologi konvensional itu selalu membicarakan pada "permasalahan langit" seperti Tuhan, malaikat, langit, akhirat, surga, kitab suci dan seterusnya. Sedangkan tema-tema yang berkaitan dengan "permasalahan bumi" seperti manusia, rakyat, dunia, bumi dan seterusnya hampir-hampir tidak pernah mendapat posisi dalam kajiannya. ${ }^{35}$ Mestinya, menurut Hasan Hanafi hal itu justru sebaliknya, sehingga dia mengatakan:

Theology is ended an antropology, that means the science of man as intention of the world and as analysis of discourse. It is as human science not a divine science. Theology as hermeneutik is not a sacred science but a humanly contructed social science. It reflects socio-political conflicts. Every social group, and a believing society reads its own interest and defends it in its belief system this is what is called theology. ${ }^{36}$

\footnotetext{
${ }^{35}$ Rumadi, Masyarakat Post-Teologi..., 13.

${ }^{36}$ Hasan Hanafi, From Faith to Revolution, Makalah ini dipresentasikan seminar di Spanyol tahun 1985, 6.
} 
Spiritualis: vol. 6, no. 2, September, 2020 |175

Pemikirsan-pemikiran teologis ${ }^{37}$ kontemporer Islam semestinya merupakan refleksi dari bawah ke atas, dari realitas di proyeksikan ke dalam teks-teks keagamaan. Sementara itu, pemikiran keagamaan (teologi) selama ini hanya bertumpu pada roll model "pengalihan" yang hanya memindahakan bunyi teks pada realitas saja. Padahal teks tidak sama dengan realitas itu sendiri. ${ }^{38}$

Alasan inilah yang meniscayakan revitalisasi dalam bidang ilmu kalam (teologi), dan diharapkan dengan perubahan epistemologi ilmu kalam (teologi), akan menjadikan up to date serta relevan dengan perkembangan zaman, dan tidak ditinggalkan oleh masyarakat. Akan tetapi jika teologi tradisional tetap dipertahankan, maka akan berpengaruh terhadap cara menafsirkan realitas sosial melalui kerangka "atas bawah", yang "atas" dikonotasikan sebagai kebaikan dan kesucian, hal ini juga bisa berarti elite yang berkuasa. Sedangkan kata "bawah" itu sendiri berhubungan degan segala bentuk yang populer, dekaden, rendah dan sangat profan, juga bisa berarti massa yang cenderung anarkis, sehingga mesti diatur dan direkayasa secara tidak disadari, stratifikasi sosial kemudian dilegitimasi melaui kenyataan wujud herarkial: Tuhan- malaikat-manusia-benda-benda.

Padahal, yang namanya teologi merupakan sebuah "ideologi" yang menjadi landasan, atau paling tidak menjadi inspirasi bagi seseorang itu sendiri atau komunitas dalam melakukan interaksi dan transformasi dalam kehidupan sosial

37 Teologi disini dipahami sebagai refleksi sistematis terhadap agama atau penafsiran terhadap realitas dalam perspektif ketuhanan.

38 E. Kusnadiningrat, Teologi dan Pembebasan, Gagasan Islam Kiri Hassn Hanafi (Yogayakarta: Logos, 1999), 3. 
yang terjadi dalam masyarakat Islam, bisa juga dikatakan tidak mempunyai pegangan, tanpa arah, disorientasi. Dengan demikian peninjauan ulang aspek doktrinal teologi Sunni merupakan keniscayaan yang tak bisa terelakkan. ${ }^{39}$

Terlepas dari kritikan yang ditonjolkan terhadap modernisme Barat, ${ }^{40}$ hal yang mendasar yang mesti diakui bahwasanya modernisme telah berjasa untuk mengusung wacana kemanusiaan sebagai suatu hal yang sangat signifikan, sebagai pusat kesadaran eksistensi diri manusia. ${ }^{41}$ Perkembangan pemikiran yang terjadi dan dialami oleh masyarakat Barat yang ditunjukkan dengan semakin meningkatnya kualitas dan kuantitas bangunan pemikiran yang berorientasi pada empiris positivistik. Realitas berkembangnya pemikiran-pemikiran yang dikembangkan oleh Karl Marx dengan dialektika materialismenya misalnya, atau Nietzce dengan kredo sucinya "God Is Dead" merupakan relaitas perkembangan pemikiran yang menempatkan manusia sebagai pusat kesadaran itu sendiri. ${ }^{42}$

Perubahan mengenai iman secara manusiawi dengan menerima keparipurnaan merupakan norma mutlak bagi kebangkitan sebuah agama, peradaban, ekonomi dan sosial. Kebangkitan bukanlah sekedar do'a-do'a yang dibaca saja,

${ }^{39}$ Rumadi, Masyarakat Post Teologi..., 13.

40 Berkaitan dengan kritik modernisme bisa dilihat misalnya dalam Musa Kazhim, "Kematian manusia sebuah Karikatur" jurnal Al-Huda, I, No. 3 (2001), 103-119; Erich From, Revolusi Harapan, terj. Kamdani (Yogyakarta: Pustaka Pelajar, 1996).

${ }^{41}$ Jostein Garder, Dunia Shopie, terj. Rahmani Astuti (Bandung: Mizan, 1997), 483-507.

42 Muhammad In'am Esha, "Kalam Aktual” Pemikiran Terhadap Upaya Realita Ilmu Kalam”, Suhuf. No.02 (2002), 100. 78 . 
bukan pula diukur melalui kriteria-kriteria sebuah perangkat, ataupun hitungan angka matematis, bahkan simbol-simbol yang telah dikibarkan. Lebih dari itu, kebangkitan justru terletak pada suatu ruh baru yang membebaskan dan memancarkan kreasi dengan sebuah pemikiran baru yang mengarah pada kebebasan bersifat krearif memunculkan kekuatan baru yang menggerakkan tatanan peradaban serta kehidupan baru masyarakat yang dapat memancarkan keindahan cemerlang. ${ }^{43}$ Oleh karena itu Hasan Hanafi sendiri sangat berambisi untuk membangun pemikiran yang bersifat teologis antroposentris yang berorientasi pada pemberdayaan rakyat. Asumsi dasarnya adalah bahwa sebuah teologi yang berkembang dan dominan di dalam dunia Islam selama berabad-abad ini, tidak bisa akrab dengan problematika kemasyarakatan sehingga sekarang harus didekonstruksi baik dari sisi epistemologinya, maupun wacana dan juga struktur bangunannya.

Senada dengan yang diungkapkan Hasan Hanafi, Amin Abdullah menjelaskan, dalam ilmu kalam kontemporer, lebih perlu mengedepankan pentingnya sebuah methodologi, fundamental theories, basic, current, living or actual issues serta comperative perspective dalam persoalan-persoalan keagamaan sehari-hari. Jika ilmu kalam mengambil jalan seperti ini, jelas hal ini bisa lebih berguna daripada sekedar menyentuh aspek sejarah dan perkembangan ilmu kalam, apalagi kalau masih saja

${ }^{43}$ Hasan Shoub, Islam dan Pemikiran, Dialog Kreatif Ketuhanan dan Kemanusiaan (Surabaya: Risalah Gusti, 1997), 24. 
Spiritualis: vol. 6, no. 2, September, 2020 |178

terfokus pada konsep-konsep abstrak yang tidak menyentuh persoalan kehidupan keseharian manusia. ${ }^{44}$

Apabila dalam kajian teologi Yunani tidak menerima eksistensi manusia untuk mengerti dirinya sendiri, maka filsafat Yunani juga tidak akan menjadi gerbang bagi para pemikir. Jika saja teologi Kristen tidak menerima penebusan penderitaan manusia, niscaya Kristen tidak akan melahirkan insan yang kasih sayang. Begitu pula jika teologi Islam yang mutlak tidak menerima kehadiran insan untuk mencapai taraf keluhuran dengan cinta dan kasih sayangnya, Islam tidak akan menjadi cinta ideal bagi insan yang bersifat pengasih dan penyayang. ${ }^{45}$

Seperti sudah diketahui dalam dunia modern dimulai dengan adanya Renaissance, yaitu suatu peradaban baru yang mencoba keluar dari kemunduran abad pertengahan, secara mainstream yang menjadi ciri modernitas ialah antroposentris. Semangat menghargai nilai-nilai yang dibangun oleh manusia itu sendiri, sebagai lawan dari teosentrisme abad pertengahan, sewaktu orang mengungulkan wahyu sebagai satu-satunya kebenaran an-sich. Dengan demikian modernisme juga berarti differentiation (pemisahan); yaitu pemisahan antara agama dengan ekonomi, agama dengan politik, agama dengan ilmu pengetahuan, ${ }^{46}$ antroposentris dan rasioanlisme sebagai ganti teosentris dan iman. ${ }^{47}$ Akan tetapi dalam hal pemikiran Hasan

\footnotetext{
${ }^{44}$ Muhammad Mansur, Kritik Hasan Hanafi Atas Pemikiran Kalam Klasik, Laporan Penelitian Individual, proyek perguruan Tinggi IAIN Sunan Kalijaga Yogyakarta tahun 1999/2000, 30.

${ }^{45}$ Hasan Sho'ub, Islam dan Revolusi, 34.

46 Ayu Utami, Tuhan Yang tak Pernah Utuh (Catatan kecil auto biografi Iman) dalam Basis, No.05-06, cetakan ke-51, Mei-Juni 2002, 13.

47 Abdul Mu'thi Muhammad Bayumi, Aqidah dan Liberasi Ummat, Telaah Pemikiran Hasan Hanafi "Min al-aqidah ila al-Tsawrab" dalam Tashwirul Afkar
} 
Hanafi dalam mindset teologi antroposentris tidak seradikal dan sesekuler pemikiran yang terjadi pada era modern tersebut.

Hasan Hanafi justru tidak setuju dengan sekularisme itu sendiri. Bagi Hasan Hanafi, sekularisme tidak mampu memecahkan persoalan umat, bahkan, semakin menjadikan rumit permaslahan yang ada. Sekularisme belum mampu untuk merealisasikan harapan manusia. Kegagalan sekularisme dalam memecahkan problematika manusia, dan bahkan semakin menambah pelik permasalahan, dikarenakan ia menjadi umat dari akidahnya. Oleh karena itu Hasan Hanafi menilai aqidah mempunyai peranan yang penting untuk menghasilkan kemajuan yang bisa diharapkan.

Dengan sinaran keimanan kita harus bisa berusaha memecahkan segala permasalahan yang ada. Jadi pandangan hidup yang bersifat teosentris dapat dilihat untuk mewujudkan dirinya dalam kegiatan keseharian yang bersifat antroposentris. Bahkan antara keduanya itu tidak dapat dipisahkan lagi. Konsekuensinya, orang yang mempunyai sikap berketuhanan dengan sendirinya berpri-kemanusiaan. Justru pengakuan yang bersifat berketuhanan yang dinyatakan dalam kegiatan ibadahibadah keseharian ditegaskan sebagai tidak mempunyai nilai apapun sebelum ia disertai dengan tindakan-tindakan yang nyata dalam rangka prikemanusiaan. ${ }^{48}$

Oleh karena itu teologi antroposentris prespektif Hasan Hanafi, yang merumukan kembali teologi tentu saja tidak bermaksud mengubah doktrin secara sentral tentang

Jurnal Refleksi Pemikiran Keagamaan Dan Kebudayaan, edisi No.9, tahun 2000, 88-89.

${ }^{48}$ Nurcholis Madjid, "Iman Dari Emansipasi Harkat Kemanusiaan” dalam Islam Doktrin dan Peradaban, h.101. 
Spiritualis: vol. 6, no. 2, September, 2020 |180

ketuhanan, tentang keesaan Tuhan (Islam:Tauhid), melainkan suatu usaha reorientasi pemahaman bersifat kegamaan baik secara individual maupun kolektif dalam kenyataan-kenyataan empiris menurut perspektif ketuhanan. ${ }^{49}$ Bagi Hasan Hanafi antara adanya Allah, terciptanya alam, dan keabadian jiwa adalah sinergi. ${ }^{50}$ Senada dengan yang diungkapkan oleh Hasan Hanafi, Dennis Carroll mengatakan bahwa teologi (ilmu kalam) adalah tidak semata-mata sebagai ilmu saja (theology as science) akan tetapi lebih dari itu, teologi dibuat sebagai kebijakan yang menjadi pengarah manusia dalam bertindak dan berdialektika dengan realitas yang sedang melingkupinya (theology as wisdom). ${ }^{51}$

Oleh karena itu pembaharuan kalam yang lebih bersifat membumi dan berdimensi sosiologis kemanusiaan merupakan keniscayaan dalam sejarah. Fazlur Rahman dengan tegas mengatakan bahwa: "Unless theology was reformulated afresh, Islam would be in real and grave danger". 52 Selama ini dalam agama Islam yang biasa menggunakan "bahasa langit" tidak bisa secara langsung menyentuh aspek sosial kehidupan manusia, sehingga secara spesifik harus perlu ditafsirkan menjadi bahasa bumi. Pada tingkat penafsiran inilah, agama yang semestinya mempunyai fungsi pembebasan justru berubah menjadi sebaliknya, yakni pengekangan melalui proses ortodoks. ${ }^{53}$

Dalam kajian kalam kontemporer, mesti berdialog dengan realitas yang berkembang dalam konteks kekinian

${ }^{49}$ Kusnadiningrat, Teologi dan Pembebasan..., 5-6

${ }^{50}$ Hasan Hanafi, Min al-'Aqidah, 73.

51 Dennis Carroll, What Is Liberation Theology (Sydney X Wellington: E.J Devyer, t.th), 24.

${ }^{52}$ Fazlur Rahman, Islam And Modernity, Transformation Of An Intelelectual Tradition (London: The University of Chicago Press, 1982), 153.

53 Rumadi, Masyarakat Post-Teologi, 49. 
Spiritualis: vol. 6, no. 2, September, $2020 \mid 181$

sebagai wujud pengembalian peran vital dan kebaruannya. Hasan Hanafi menjelaskan bahwa falsafah Islam, termasuk kalam, perlu bergumul, bersentuhan serta berinteraksi dengan diskursus falsafah yang hidup dalam kesadaran dan kebudayaan Eropa, yang sudah berhasil membedah persoalan-persoalan kemanusiaan (antropologi) dan menempatkannya sebagai persoalan yang lebih pokok untuk ditelaah dan dikaji, daripada hanya terjebak pada persoalan-persoalan ketuhanan klasik semata. $^{54}$

Dalam konteks ini, Hasan Hanafi bisa dikatakan sangat kental dengan warna eksistensialisme Barat. Hal ini dengan jelas dapat dicermati dari ide-ide yang ditawarkan seperti pentingnya aspek kemanusian yang harus dikedepankan dalam diskursus keilmuan Islam kontemporer. Pembaharuan dalam bidang keilmuan Islam yang sarat dengan jargon-jargon pembebasan juga harus digalakkan. Realitas ini memberikan pemahaman bahwa betapa eksistensi manusia mempunyai posisi yang signifikan dalam konsep pemikiran yang di gagasnya. Bagi Hasan Hanafi umat Islam yang sedang dilanda penindasan, keterbelakangan, kemiskinan dan kemunduran dalam peradabanya harus mempunyai kesadaran "aku", kesadaran akan eksistensinya, untuk mengatasi realitas-realitas permaslahan tersebut. ${ }^{55}$

Teologi (kalam) menurut Hasan Hanafi memerlukan pijakan dasar 'aqaliyah, sekaligus juga berpijakan pada dasar kenyataan Tauhid yang harus dikaitkan dengan perbuatan,

\footnotetext{
${ }^{54}$ Hasan Hanafi, Dirasāt, 204-205.

${ }^{55} \mathrm{Hal}$ ini misalnya, secara jelas tampak pembahasannya tentang ilmu ushuluddin yang menegaskan pentingnya kesadaran diri umat Islam dalam melihat realitas. Lebih lanjut lihat Hasan Hanafi, Min al-'Aqidah Ila al-Thawrah, 9.
} 
Spiritualis: vol. 6, no. 2, September, $2020 \mid 182$

Allah dengan bumi, dzat Tuhan harus bisa dikaitkan dengan kepribadian manusia, sifat-sifat Tuhan bisa dikaitkan dengan niali-nilai kemanusiaan, kehendak Tuhan dikaitkan dengan kebebasan manusia, kemauan Tuhan dan gerakan sejarah. ${ }^{56}$ Inilah yang membedakan dalam pemikiran Hasan Hanafi dengan para teolog konservatif yang terhenti pada pijakan dasar akaliah dengan teologi kontemporer yang juga menggunakan pijakan dasar kenyataan saja.

Menurut Hasan Hanafi, akal dan kenyataan merupakan dasar dari penerimaan kebenaran pengetahuan mengenai mana yang benar dan yang salah, tidak serta merta datang dari atas, melainkan dari perenungan diri sendiri atas data-data pemikiran dan kenyataan. Pengetahuan teoritis tidak merupakan sebuah anugerah, melainkan dapat diperoleh melalui analisis bersifat rasional yang cermat terhadap ide-ide dan kenyataan dengan meneliti terjadinya berbagai fenomena peristiwa. Hal ini bukan berarti penolakan terhadap adanya sebuah ukuran-ukuran kebenaran dan garis-garis yang mengatur sebuah pemikiran. Ini semua ada, muncul dari tabiat akal manusia sendiri serta ditangkap melalui intuisi, tidak berasal dari luar. Jadi, sesuatu hal yang baru bisa dikatakan benar, manakala akal telah menyelidikinya terlebih dahulu dan membuktikannya dalam kenyataan bahwa itu memang benar. ${ }^{57}$

Masyarakat Muslim dalam konteks modern sekarang ini, sedang menghadapi berbagai problematika kehidupan baik yang berkaitan dengan fenomena penjajahan, penindasan, keterbelakangan, kemiskinan, stagnasi pemikiran maupun hegemoni perdaban Barat sekuler dan semakin

${ }^{56} \mathrm{Ibid}, 32$.

${ }^{57}$ Ibid., 8. 
Spiritualis: vol. 6, no. 2, September, 2020 |183

mengedepannya dimensi kesejarahan soisal dan kemanusiaan dalam diskursus kontemporer, realitas itulah yang mendorong Hasan Hanafi melakukan shifting paradigms, dari ilmu Allah menuju ilmu manusia, dari dasar-dasar agama menuju bersifat bergumul (peduli) pada masyarakat. Ia mengubah dasar lama menjadi kebenaran di masa kini. ${ }^{58}$

Menurut Hasan Hanafi, masa saat ini merupakan masa pembaharuan dan kebangkitan, generasinya merupakan generasi perubahan dan revolusi. Para penulisnya, seharusnya, tidak melacurkan diri pada penguasa keagamaan atau politik, tetapi membela kepentingan rakyat melawan semua penguasa. Yang perlu diperhatikan bukanlah yang sudah cukup dan yang sudah baik, melainkan yang kurang dan belum terlaksana. Bukanlah Allah yang Maha sempurna yang menjadi persoalan, melainkan umat yang terjajah dan teraniaya. ${ }^{59}$ Kalam klasik yang pembahasannya tidak beranjak dari terma-terma alilähiyah, al-mantiqīyah dan al-tābi $\bar{y} y a h$ adalah sudah tidak relevan dengan konteks realitas pemikiran kontemporer. Kalam yang dianggap sebagai ilmu paling fundamental dalam tradisi Islam karena berkaitan dengan aspek-aspek keyakinan manusia itu sendiri harus direkontruksi sesuai dengan kebutuhan manusia, dan sesuai dengan standar modernitas. ${ }^{60}$

Teologi (kalam) yang digagas oleh Hasan Hanafi bukan lagi menjadikan kalam sebagai media apologis dimensi "kelangitan", tetapi diarahkan kepada bagaimana teologi (kalam) mampu berdialektika dengan realita yang sedang dialami oleh manusia kotemporer. Oleh karena itu, teologi

58 Ibid., 74-75.

${ }^{59}$ Hasan Hanafi, Min al-'Aqidah Ila al-Tsawrah,I, h. 11, 30-32

60 Ibid, 72-75. 
Spiritualis: vol. 6, no. 2, September, $2020 \mid 184$

(kalam) tidak lagi ilmu yang berbicara tentang dimensi ketuhanan secara murni saja, tetapi lebih pada bagaimana pemahaman tentang dimensi ketuhanan tersebut mampu ditrasformasikan serta dapat mengokohkan eksistensi kemanusiaan dalam realitas "kebumiannya" dari Tuhan menuju bumi, dari dzat Tuhan menuju kepribadian manusia. Nilai-nilai kemanusiaan diinteraksikan dari sifat-sifat Tuhan, dari kekuasaan Tuhan menuju kemampuan untuk berpikir bagi manusia, dari keabadian Tuhan menuju gerakan kesejarahan manusia, dari eskatologis menuju masa depan kemanusiaan. ${ }^{61}$ Oleh karena itu, lebih lanjut Hasan Hanafi mengatakan:

The purpose of this new contruction of the traditional belief system is not to obtion eternal life by knowing the truth, but to acquire success in this world by fulfiling the hopes of the muslim world for liberation, freedom, justice, social equality, reunification, identity, progress and mass mobilization therefore, theology as a science is of the first importance because it is the theoritical analysis of action. Behavioural science are simple applications of beliefe system. Bath ate work human mind directed and oriented towards the world by revelation. ${ }^{62}$

Dalam sebuah perubahan paradigma itu menyangkut beberapa hal. Pertama, merubah paradigma teologi yang teosentris (Tuhan pusat segala sesuatu) menjadi lebih ke antroposentris (manusia menjadi pusat segala sesuatu). Jika paradigma pertama melihat urusan dunia sebagai urusan Tuhan, maka dalam paradigma kedua melihat urusan dunia itu

${ }^{61}$ Hasan Hanafi, Islam In The Modern World: Religion, Ideologi and Development (Heliopolis Dar Kebaa Bookjshop, t.th), 11-22.

62 Ibid, 124-125. 
Spiritualis: vol. 6, no. 2, September, $2020 \mid 185$

sebagai urusan manusia. Kedua, merubah cara berfikir terhadap dunia sebagai segala sesuatu yang menyatu dengan Tuhan sehingga harus selalu didekati dengan cara perspektif keTuhan-an yang menjadikan sebuah teologi melihat dunia sebagai sesuatu yang terpisah dengan Tuhan. Sehingga cara pandang tentang dunia tidak selalu didekati dengan prespektif Ilahi, meskipun yang bersifat Ilahi tidak dapat ditolak sama sekali. Ketiga, merubah cara pandang terhadap alam sebagai "tanda" kehadiran Tuhan menjadi tanda atau instrumen untuk menyembah Ilahi. Keempat, menggeser cara pandang teologi yang menjadikan individu sebagai titik fokus dan titik tolak dalam memandang kenyataan hidup. Konsekuensi dari hal ini adalah konsep kesalihan dengan sendirinya menjadi berubah, dari sebuah kesalihan ritual individual menjadi sebuah kesalihan sosial. ${ }^{63}$

\section{Kesimpulan}

Teologi (ilmu kalam) dalam ajaran Islam menempati posisi yang paling inti dalam kehidupan beragama. Dalam teologi klasik pembahasan mengenai isi dari teologi hanya bersifat sebuah teori-teori yang bersifat "melangit" belum sampai pada taraf kehidupan sosial bermasyarakat, ajaran teologi inilah yang mendapatkan kritikan dari Hasan Hanafi.

Hasan Hanafi berpendapat bahwa ajaran teologi Islam klasik yang masih digunakan sampai sekarang ini perlu adanya sebuah inovasi dan evolusi yang bernuansa pembebasan dari dalam. Dari sebuah teologi yang membahas masalah-masalah yang sifatnya melangit-teosentris, menuju kepada teologi yang

${ }^{63}$ Rumadi, Masyarakat Post, Teologi, 34. 
lebih bersifat membumi-antroposentris, supaya bisa diaplikasikan dalam kehidupan manusia dalam keseharian. Ilmu kalam dianggap sebagai ilmu paling fundamental dalam tradisi Islam karena berkaitan dengan aspek-aspek keyakinan manusia itu sendiri. Dengan demikian, ilmu tersebut harus direkontruksi sesuai dengan kebutuhan manusia, dan sesuai dengan standar modernitas.

Perlu diingat bahwa kritikan yang ditawarkan oleh Hasan Hanafi sama sekali tidak menghilangkan teologi yang bersifat teosentris, justru, menurut Hasan Hanafi dari pijakan awal teologi yang bersifat teosentris "melangit" digunakan sebagai pijakan untuk menuju teologi yang bersifat antroposentris "membumi". Dari sebuah teologi teosentris diarahkan kepada bagaimana teologi (kalam) mampu berdialektika dengan realita yang sedang dialami oleh manusia kotemporer. Oleh karena itu, teologi (kalam) tidak lagi ilmu yang berbicara tentang dimensi ketuhanan secara murni saja, tetapi lebih pada bagaimana pemahaman tentang dimensi ketuhanan tersebut mampu ditrasformasikan serta dapat mengokohkan eksistensi kemanusiaan dalam realitas "kebumiannya" dari Tuhan menuju bumi, dari dzat Tuhan menuju kepribadian manusia. Nilai-nilai kemanusiaan diinteraksikan dari sifat-sifat Tuhan, dari kekuasaan Tuhan menuju kemampuan untuk berpikir bagi manusia, dari keabadian Tuhan menuju gerakan kesejarahan manusia, dari eskatologis menuju masa depan kemanusiaan.

Lebih lanjut menurut Hasan Hanafi masa saat ini merupakan masa pembaharuan dan kebangkitan, generasi pada masa sekarang merupakan generasi perubahan dan revolusi. Para ilmuwanya, seharusnya, tidak melacurkan diri pada 
penguasa keagamaan atau politik, tetapi membela kepentingan rakyat melawan semua penguasa. Yang perlu diperhatikan bukanlah yang sudah cukup dan yang sudah baik, melainkan yang kurang dan belum terlaksana. Bukanlah Allah yang Maha sempurna yang menjadi persoalan, melainkan umat yang lemah, terjajah dan teraniaya seharusnya mendapatkan perhatian yang lebih, karena sebuah teologi pembebasan bisa merubah umat manusia dari kesengsaraan menuju kemerdekaan hidup yang hakiki serta merdeka dalam berfikir, berekonomi dan berdaulat penuh atas dirinya sendiri. 
Spiritualis: vol. 6, no. 2, September, 2020 |188

\section{DAFTAR PUSTAKA}

Abdullah, Amin. Filsafat Kalam Di Era Postmodernisme. Yogyakarta: Pustaka Pelajar, 1995.

Azhar, Muhammad dkk, Studi Islam dalam Percakapan Epistemologis. Yogyakarta: Sipres, 1998.

Bayumi, Abdul Mu'thi Muhammad. Aqidah dan Liberasi Ummat, Telaah Pemikiran Hasan Hanafi "Min al-'Aqidab ila alThawrah” dalam Tashwirul Afkar Jurnal Refleksi Pemikiran Keagamaan Dan Kebudayaan, edisi No. 9, tahun 2000.

Carroll, Dennis. What Is Liberation Theology. Sydney X Wellington: E.J Devyer, t.th.

Enginer, Asghar Ali. Islam dan Teologi Pembangunan,terj. Agung Prihantoro. Yogyakarta: Pustaka Pelajar, 1999.

Esha, Muhammad In'am "kalam Aktual" Pemikiran Terhadap Upaya Realita Ilmu Kalam”, Suhuf. No.02 (2002).

Garder Jostein, Dunia Shopie, terj. Rahmani Astuti, Bandung: Mizan, 1997

Gusmian, Ishlah. Teologi Pembebasan dari Membela Manusia: Sekilas Gagasan Ashgar Ali Enginer dalam Muhiddin M. Dahlan (ed), Sosialisme Religius. Yogyakarta:Kreasi Wacana, 2010.

Gutterez, Gustavio. A Teology of Liberation, New York: Maryknell, 1973.

Hamzah, Teologi Sosial: Telaah Pemikiran Hasan Hanafi, Yogyakarta: Graha Ilmu, 2013.

Hanafi, Hasan. Dari Akidah ke Revolusi: Sikap Kita Terhadap Tradisi Lama, Terj. Miftah Faqih, Jakarta: Paramadina, 2003.

------- Agama, Ideologi, dan Pembangunan. Jakarta: P3M, 1991.

----------- Dirasah Islamiyyah, Kairo: Maktabah alMishriyyah, t.th. 
----------, Islam In The Modern World: Religion, Ideologi and Development. Heliopolis Dar Kebaa Bookjshop, t.th.

------, Islamologi 3: Dari Teosentrisme ke Antroposentrisme, Terj. Miftah Faqih, Yogyakarta: LKis 2004. --------, Min al-'Aqidah Ila al-Thawrab; Muhawalatun Li I'adat Bina' Ushul al-Din, Kairo: Maktabah Madbuli. t.th.

Hefni, Moh. "Rekonstruksi Maqashid al-Syariah (Sebuah Gagasan Hasan Hanafi tentang Revitalisasi Turats), Jurnal al-Hikam. Vol. 6 No. 2 Desember 2011.

Kazhim, Musa. "Kematian Manusia Sebuah Karikatur". Jurnal AlHuda, I, No. 3 (2001). From, Erich Revolusi Harapan, terjemahan Kamdani, Yogyakarta: Pustaka Pelajar, 1996.

Kusnadiningrat, E. Teologi dan Pembebasan, Gagasan Islam Kiri Hasan Hanafi. Yogayakarta: Logos, 1999.

Madjid, Nurcholis. Aktualisasi Ajaran Aswaja dalam Islam Menatap Masa Depan. Jakarta: P3M, 1989.

Mansur, Muhammad. Kritik Hasan Hanafi Atas Pemikiran Kalam Klasik, laporan Pnelitian Individual, proyek perguruan Tinggi IAIN Sunan Kalijaga Yogyakarta tahun 1999/2000, Nurhakim, Moh. Neo Modernisme Dalam Islam, Malang: UMM Press, 2001.

Pribadi, Airlangga \& M. Yudhie R. Haryono, Post Islam Liberal Membangun Dentuman Mentradisikan Eksperimentasi. Jakarta PT. Pasarindo Bunga Mas Nagari, 2002.

Rahman, Fazlur. Islam and Modernity, Transformation Of An Intelelectual Tradition. London: The University of Chicago Press,1982.

Riddah, Abdul Hadi Abu. Ummabāt al-Masa'il Fi Fikri al-Islami, dalam Al-Qabas nomor 6343, 05 Januari 1990.

Ridwan, AH. Reformasi Intelektual Islam, Pemikiran Hasan Hanafi Tentang Reaktualisasi Tradisi keilmuan Islam. Yogyakarta: Ittaqa Press, 1998.

Rumadi, Masyarakat Post-teologi, Wajah Baru Agama dan Demokratisasi Indonesia. Jakarta: CV Mustika Bahmid, 2002. 
Spiritualis: vol. 6, no. 2, September, $2020 \mid 190$

Shimogaki, Kazuo. Kiri Islam: Antara Modernisme dan Posmodernisme, terj. M. Imam Aziz dan M. Jadul Maulana, Yogyakarta: LKis, 2007.

Sholeh, A. Khudori, Filsafat Islam. Sleman: Ar-Ruzz Media, 20014.

Shoub, Hasan. Islam dan Pemikiran, Dialog Kreatif Ketubanan dan Kemanusiaan. Surabaya: Risalah Gusti, 1997.

Suharti, "Gagasan Kiri Islam Hasan Hanafi", Ulumuna,Vol. IX Edisi 16 Nomor 2 Juli-Desember 2005.

Yusdani, Gerakan Pemikiran Kiri Islam: Studi Atas Pemikiran Hasan Hanafi, Jurnal Al Mawarid, Edisi VII 2002. 